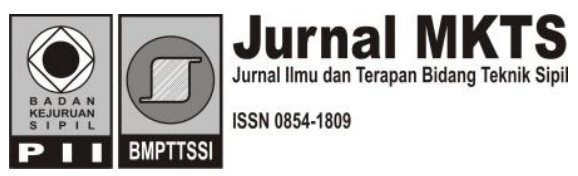

\title{
Pengaruh Land Subsidence terhadap Genangan Banjir dan Rob di Semarang Timur
}

\author{
Ratih Pujiastuti \\ Pusat Studi Bencana, LPPM Universitas Diponegoro \\ Gedung Widya Puraya \\ Jl.Prof. Soedarto, SH, Tembalang, Semarang 50275
}

E-mail: ratyih@yahoo.com

\author{
Suripin \\ Jurusan Teknik Sipil, Fakultas Teknik, Universitas Diponegoro \\ Jl.Prof. Soedarto, SH, Tembalang, Semarang 50275 \\ E-mail: suripin.ar@gmail.com \\ Syafrudin \\ Program Studi Ilmu Lingkungan, Universitas Diponegoro \\ Jl.Prof. Soedarto, SH, Tembalang, Semarang 50275 \\ E-mail: udin_syaf@yahoo.com
}

\begin{abstract}
Inundation of flood and rob (flood due to high tides) in Semarang City is increase wtithin area and depth. It be more seroius condition because of land subsisdence that happened in coastal area of Semarang City. This research is foccused on prediction and mapping of inundation flood and rob due to land subsidence effect in East Semarang, especially Tenggang Watershed and Sringin Watershed. On this research, data analysis including analysis of land subsidence, analysis of hydrological data, analysis of flood discharge with HECHMS, hydraulics analysis with HEC-RAS and then mapping the results of the flood inundation with Arc GIS. The inundation will be create with overlay the DEM of flood water level and DEM of topographic. According to the results of analysis is known that minimum land subsidence is $0 \mathrm{~cm} / y e a r$ that happened in south area of Semarang and more higher ini north area with maximum land subsidence is $5.58 \mathrm{~cm} / y e a r$. On periode 2014-2031, the contribute of land subsidence to increase the inundation of flood and rob is 1.39\%/year.
\end{abstract}

Keywords: Irrigation swamp area, Irrigation system performance, Potential water and land, Optimalization.

\begin{abstract}
Abstrak
Genangan banjir dan rob di Kota Semarang semakin meningkat luas dan kedalamannya dari waktu ke waktu. Salah satu penyebabnya adalah penurunan muka tanah/land subsidence yang terjadi wilayah pesisir Kota Semarang. Penelitian ini menitikberatkan pada prediksi dan pemetaan dampak land subsidence terhadap genangan banjir dan rob di Semarang Timur, khususnya DAS Tenggang dan DAS Sringin. Tahapan analisis data mencakup analisis land subsidence, analisis hidrologi, analisis debit banjir dengan HEC-HMS dan analisis hidrolika dengan HEC-RAS. Output HEC-RAS akan digunakan untuk mengembangkan DEM tinggi muka air banjir. Genangan banjir dan rob dianalisis dengan bantuan Arc GIS dengan menumpangsusunkan peta DEM tinggi muka air banjir dengan DEM muka tanah. Dari hasil analisis diperoleh laju penurunan muka tanah/land subsidence berkisar antara 0 di wilayah selatan dan semakin utara semakin besar dengan nilai terbesar mencapai -5,58 cm/tahun. Selama kurun waktu 17 tahun (20142031) kontribusi land subsidence terhadap kenaikan genangan banjir dan rob di DAS Tenggang dan Sringin adalah sebesar 1,39\% per tahun.
\end{abstract}

Kata-kata Kunci: Irigasi lahan rawa, Kinerja jaringan irigasi, Potensi air dan lahan, Optimalisasi. 


\section{Pendahuluan}

Perkembangan kota diakibatkan oleh jumlah penduduk dan kegiatan-kegiatan kota seperti perumahan, perkantoran, perdagangan, perindustrian dan lain-lain sehingga meningkatkkan kebutuhan terhadap air tanah. Fenomena tersebut menimbulkan kecenderungan perubahan daya dukung sumber daya air tanah, sedangkan di pihak lain terjadi penurunan volume atau debit pengisian kembali air tanah. Selain itu pengambilan air tanah secara besar-besaran tanpa diimbangi dengan pengisian kembali air tanah yang seimbang menyebabkan penurunan muka air tanah. Penurunan muka air tanah ini dapat menyebabkan amblesnya permukaan tanah dan intrusi air laut (Asdak, 1995). Terjadinya penurunan muka tanah mengakibatkan permukaan air laut lebih tinggi dari permukaan tanah, kejadian ini dikenal dengan banjir pasang air laut (rob). Penurunan muka tanah merupakan permasalahan yang umum terjadi di kota - kota besar. Penurunan muka tanah merupakan hal yang serius terutama apabila penurunan muka tanah terjadi di daerah pesisir pantai. Kondisi tersebut karena daerah pesisir sangat rentan terhadap tekanan lingkungan, baik yang berasal dari daratan maupun dari lautan.

Wilayah Kota Semarang memiliki permasalahan banjir dan rob yang seringkali menyebabkan terhambatnya aktivitas penduduknya. Bencana banjir ini mengakibatkan kelumpuhan aktivitas sosial ekonomi masyarakat hingga tidak berfungsinya sarana prasarana perkotaan yang ada, seperti bandara dan stasiun. Genangan banjir dan rob semakin serius dan meningkat luas dan kedalamannya dari waktu ke waktu.

Genangan banjir dan rob di Semarang bagian utara diperparah pula dengan penurunan muka tanah. Penurunan tanah merupakan hal yang serius terutama apabila terjadi di daerah pesisir pantai. Kondisi tersebut karena daerah pesisir sangat rentan terhadap tekanan lingkungan, baik yang berasal dari daratan maupun dari lautan (Yuwono et al. 2013).

Pengelolaan sistem drainase saat ini belum memperhitungkan faktor dampak penurunan muka tanah. Hal ini menyebabkan penanganan terhadap banjir dan rob di Kota Semarang belum dapat dituntaskan. Penelitian ini dimaksudkan untuk memprediksi dan memetakan dampak land subsidence terhadap genangan banjir dan rob di Semarang Timur, untuk mendukung pengelolaan sistem drainase perkotaan yang optimal. Sedangkan tujuan dari penelitian ini adalah untuk menganalisis penurunan muka tanah, menganalisis pengaruh land subsidence terhadap genangan banjir dan rob serta menggambarkan genangan banjir dan rob kondisi existing dan hasil prediksi mendatang sebagai akibat dari land subsidence. Wilayah yang akan dikaji dalam penelitian ini adalah Kali Tenggang dan Kali Sringin yang masuk dalam Sistem Drainase Semarang Timur. Secara administrasi, sistem ini meliputi Kecamatan Genuk, Kecamatan Pedurungan dan Kecamatan Gayamsari Kota Semarang.

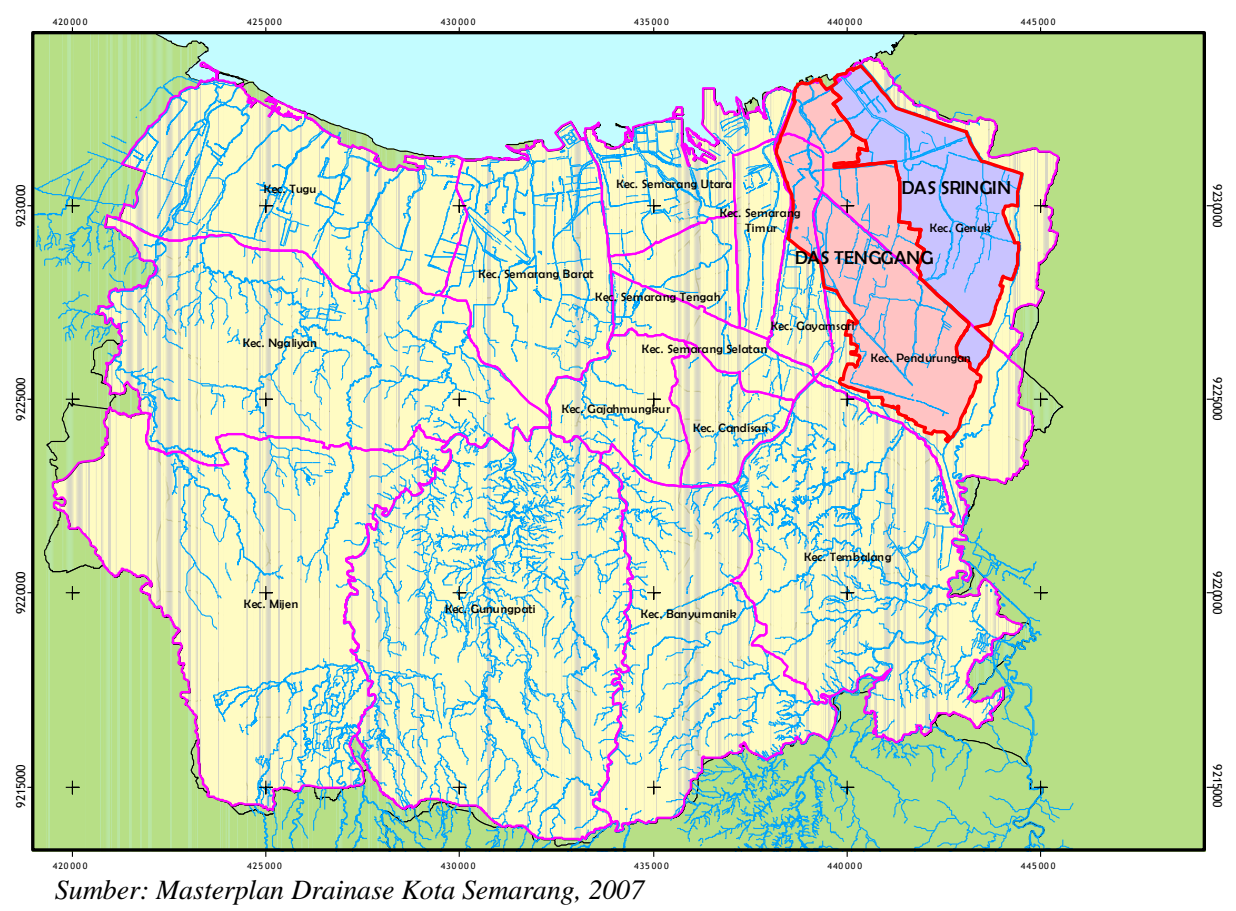

Gambar 1. Peta lokasi DAS Tenggang dan DAS Sringin. 
Kota Semarang sebagai Ibukota Provinsi Jawa Tengah memiliki karakteristik geografis yang unik di mana wilayah Semarang terbagi menjadi dua yaitu dataran rendah di bagian utara dan dataran tinggi di bagian selatan. Wilayah Semarang bagian utara merupakan dataran rendah yang berada di pesisir pantai utara Pulau Jawa. Kegiatan industri dan fasilitas umum perkotaan seperti perkantoran, perdagangan, jasa, pendidikan, kesehatan serta sarana transportasi (Bandara Ahmad Yani, stasiun kereta api, pelabuhan dan terminal) berada di wilayah tersebut. Sedangkan wilayah Semarang bagian selatan merupakan daerah perbukitan, yang dimanfaatkan sebagai lahan konservasi, area pemukiman dan pendidikan (Yuwono et al., 2013). Indikasi penurunan muka tanah di Semarang dapat diketahui dari beberapa sumber data. Berdasarkan pengukuran dan data penurunan muka tanah di daerah perbukitan di Kota Semarang lebih kecil dibanding penurunan di daerah pantai. Dari pengamatan lapangan penurunan muka tanah di kawasan bekas rawa dan tambak menunjukkan penurunan yang paling besar, misal di perumahan Tanah Mas, Pantai Tanjung Mas, dengan penurunan antara 5,5-7,23 cm per tahun (Wahyudi, 2001).

\section{Metode dan alat}

Analisis penurunan muka tanah (land subsidence) diperoleh dari data pengukuran peneliti terdahulu
(Abidin, 2011). Sedangkan analisis debit banjir dilakukan dengan menggunakan perangkat lunak "HEC HMS". Hyetograf dengan kala ulang 25tahunan durasi 2-jam digunakan dalam studi ini. Analisis hidrolika dilakukan dengan menggunakan perangkat lunak HEC RAS. Genangan banjir dan rob dianalisis dengan bantuan Arc GIS dengan menumpangsusunkan peta DEM tinggi muka air banjir dengan DEM muka tanah.

Adapun urutan pelaksanaan penelitian meliputi beberapa kegiatan dan tahapan yang secara skematis ditunjukkan pada Gambar 2.

\section{Hasil dan Pembahasan}

Data penurunan muka tanah yang digunakan dalam penelitian ini adalah berupa data pengukuran muka tanah yang dilakukan pada beberapa titik di wilayah Kota Semarang. Pengukuran muka tanah dilakukan pada dua tahun antara lain tahun 2008 dan 2011. Dari hasil pengukuran muka tanah tersebut dapat diketahui penurunan tanah di masing-masing titik pengukuran tiap tahunnya. Dari data yang ada diketahui bahwa penurunan muka tanah rata-rata adalah $2,63 \mathrm{~cm} / \mathrm{th}$, maksimum sebesar 5,58 cm/th dan minimum $0,27 \mathrm{~cm} / \mathrm{th}$.

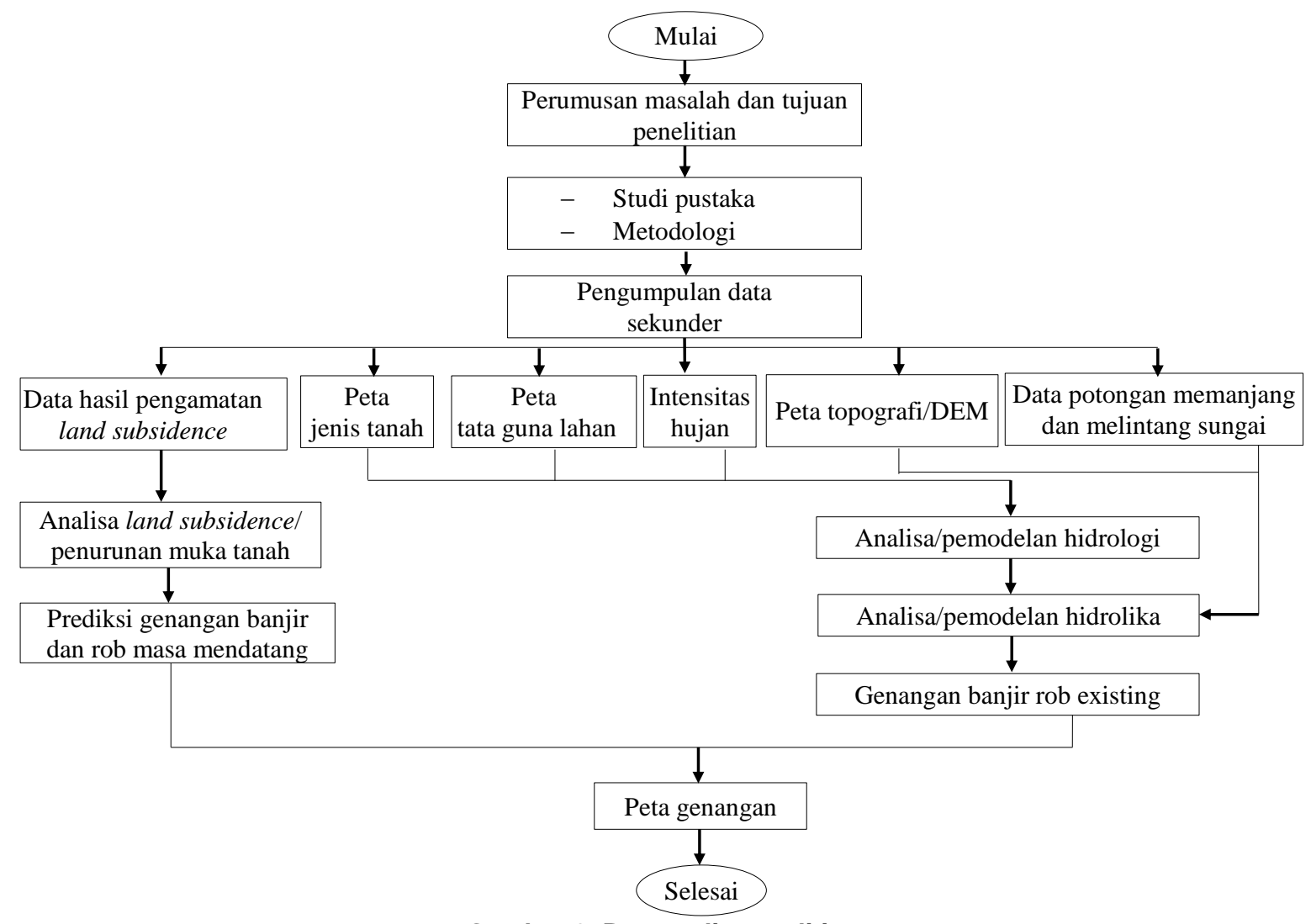

Gambar 2. Bagan alir penelitian 


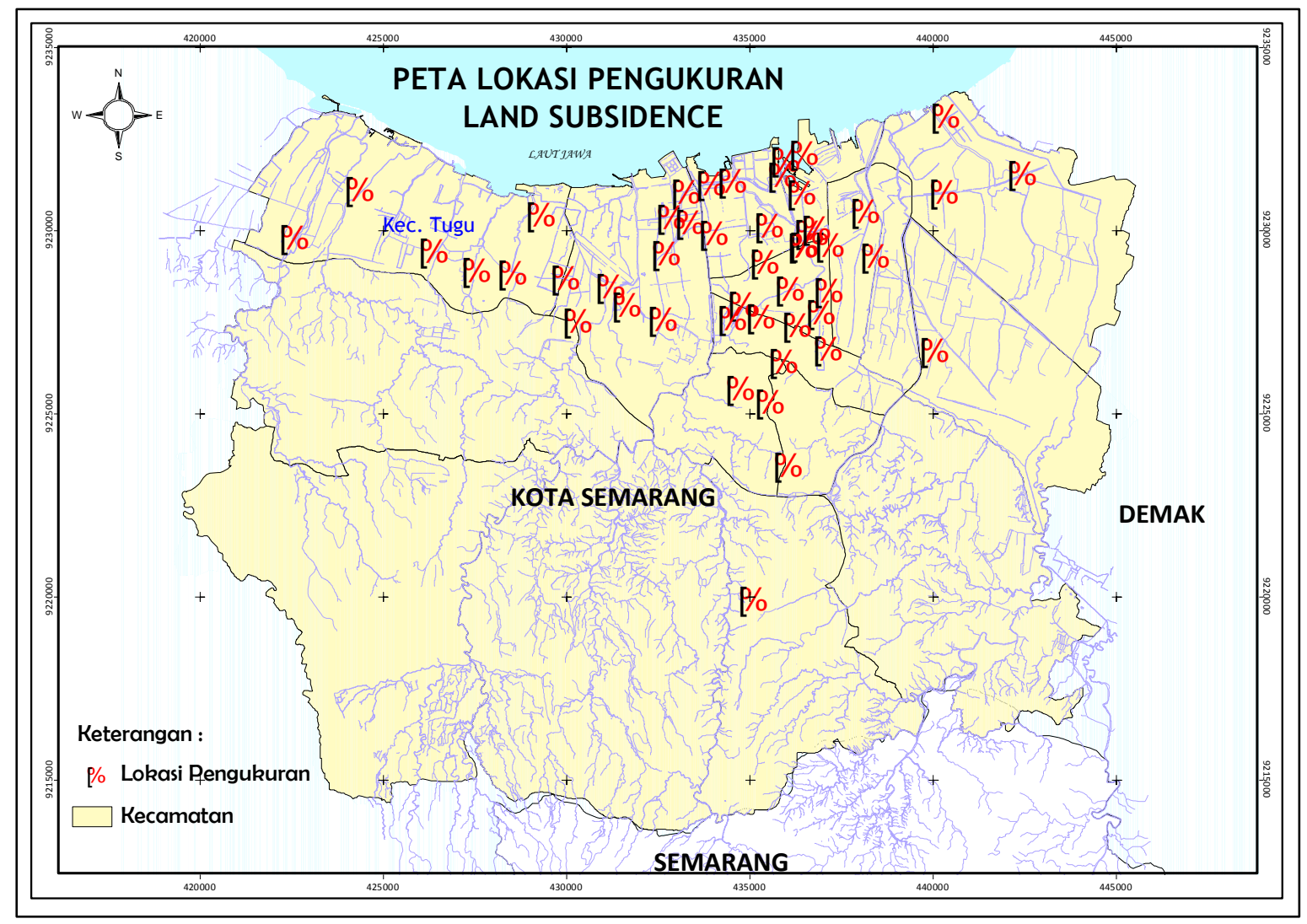

Sumber: Abidin, 2011

Gambar 3. Peta data lokasi pengukuran land subsidence

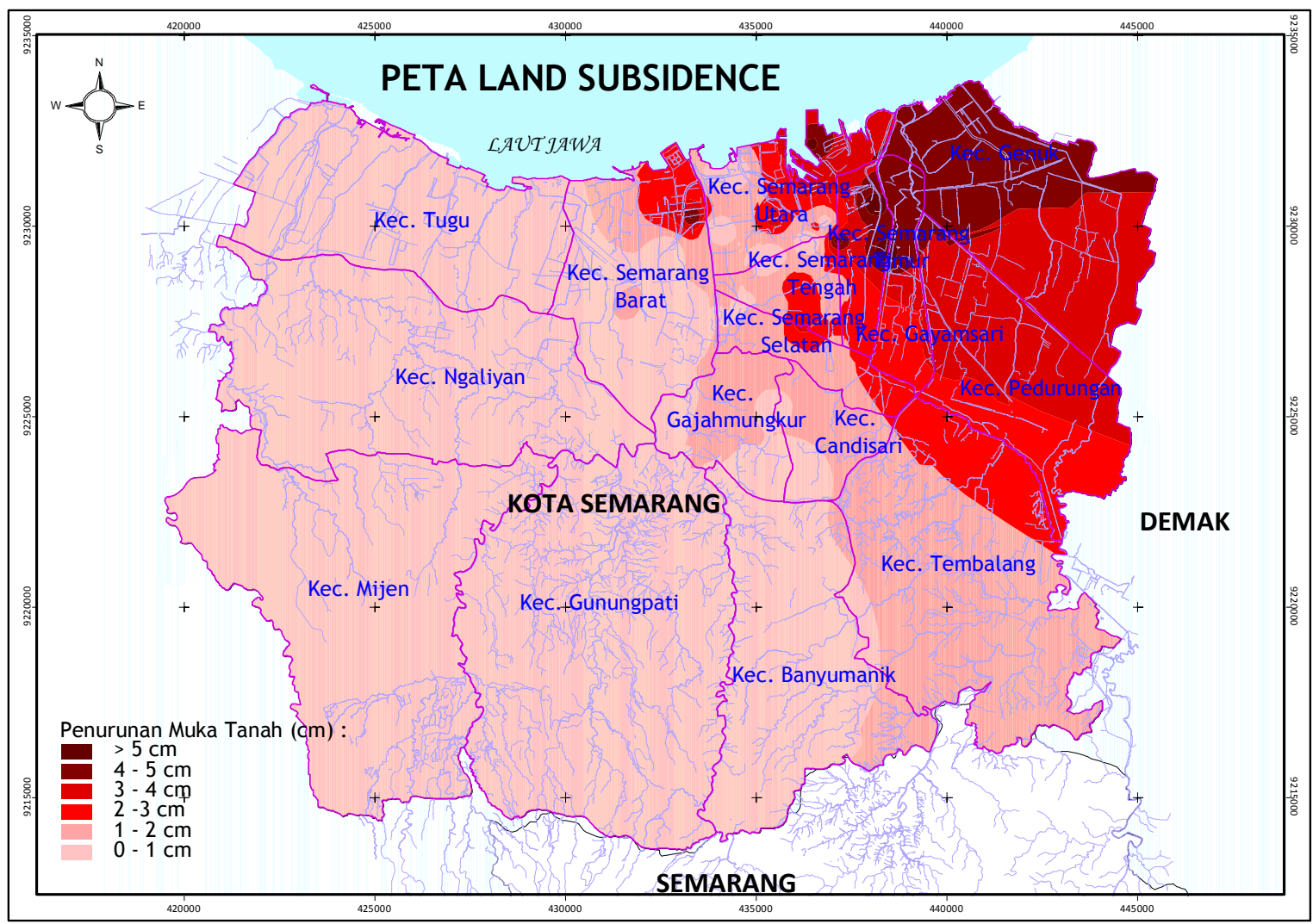

Gambar 4. Peta penurunan muka tanah di wilayah Kota Semarang 
Dari Gambar 4, diketahui bahwa penurunan muka tanah paling tinggi yaitu $>5 \mathrm{~cm}$ terjadi pada sebagian kecil Kecamatan Semarang Timur dan Kecamatan Gayamsari. Sedangkan penurunan muka tanah antara 4-5 cm mayoritas terjadi pada Kecamatan Semarang Timur, Kecamatan Gayamsari dan Kecamatan Genuk. Penurunan muka tanah antara 3-4 cm dan 2-3 cm terjadi pada sebagian besar wilayah Kecamatan Pedurungan, bagian hulu Kecamatan Genuk dan bagian hilir Kecamatan Tembalang. Penurunan muka tanah rendah yaitu 1-2 cm dijumpai pada wilayah Kecamatan Tembalang, Kecamatan Candisari, Kecamatan Gajah Mungkur dan Kecamatan Semarang Barat.

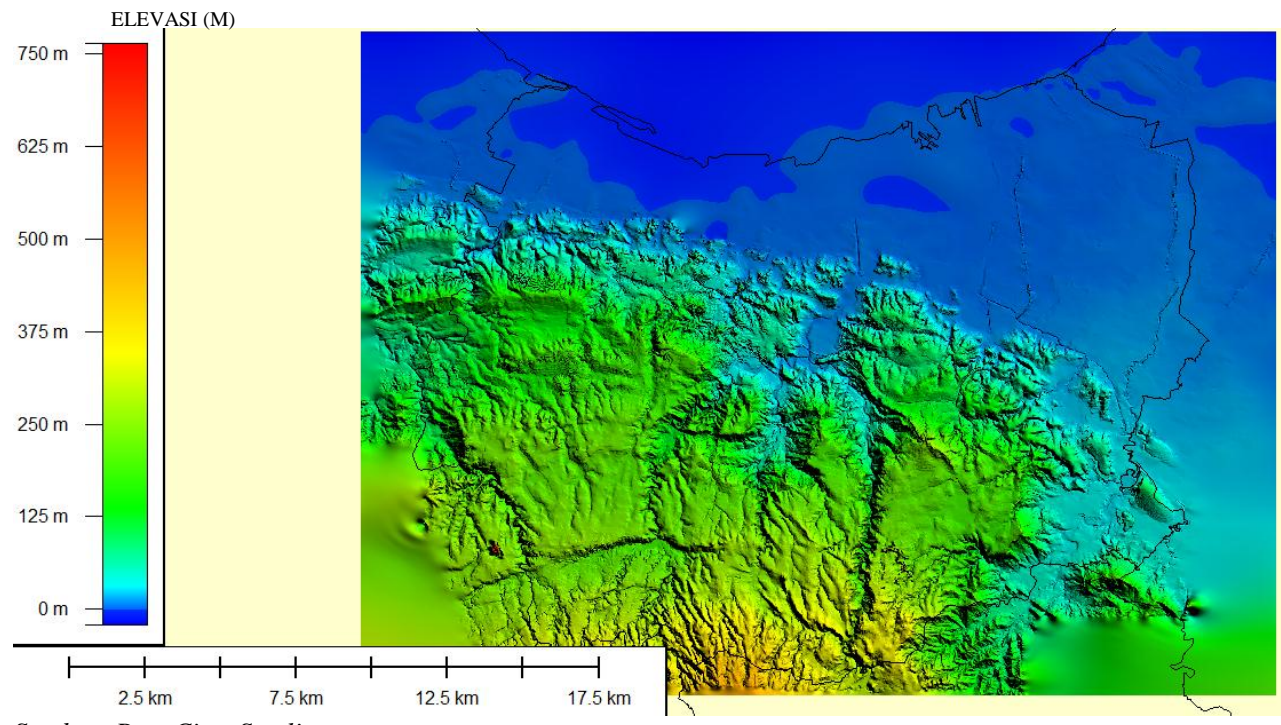

Sumber: Peta Citra Satelit

Gambar 5. Peta DEM/topografi Kota Semarang tahun 2008

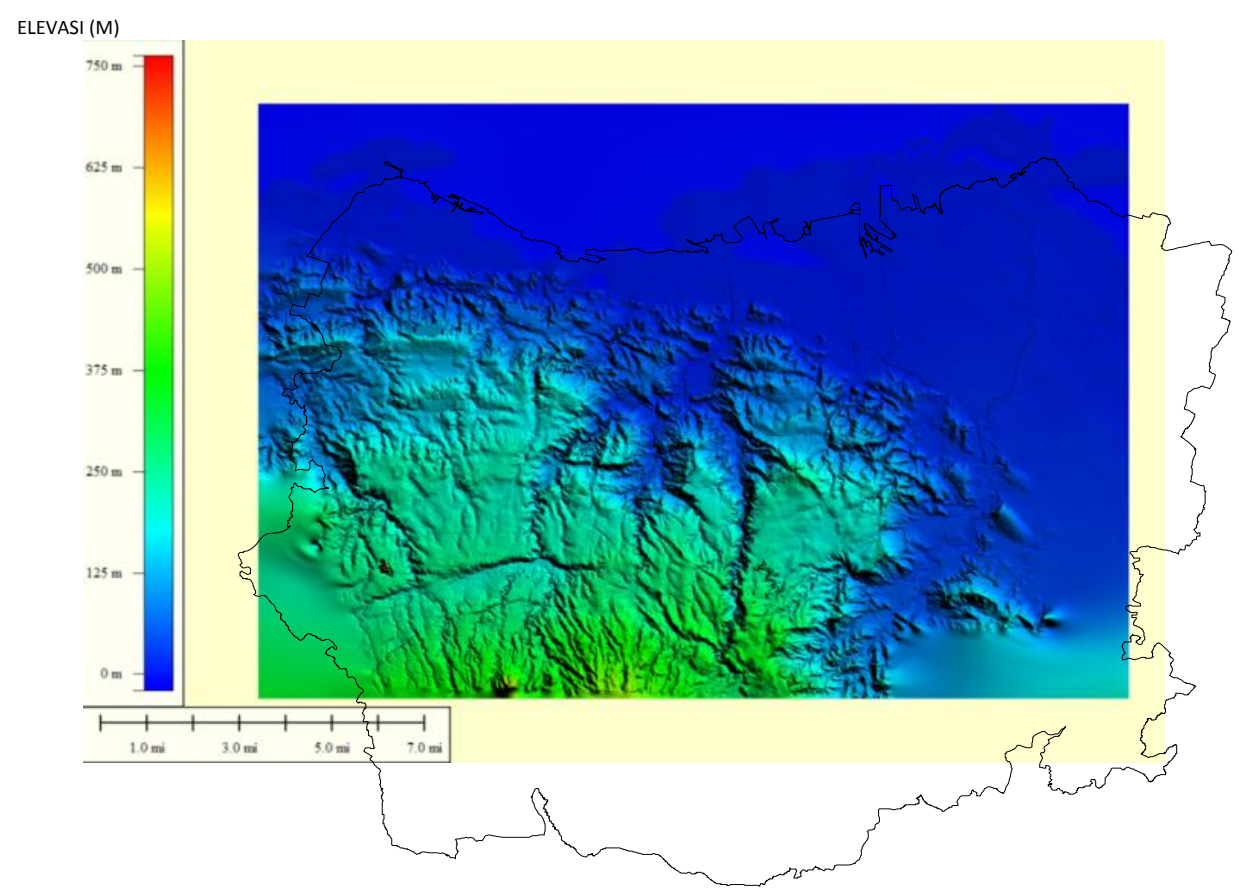

Gambar 6. Peta DEM/topografi Kota Semarang tahun 2031
Peta penurunan muka tanah digunakan untuk mengetahu kondisi topografi pada masa mendatang. Kondisi topografi existing Kota Semarang terbagi menjadi dua wilayah, yaitu wilayah kota lama yang merupakan dataran rendah yang berdekatan dengan pantai, sering disebut sebagai Semarang bagian bawah, serta daerah pengembangan kota kearah selatan pada area yang berbukit bukit berupa dataran tinggi yang disebut sebagai Semarang bagian atas. Peta DEM yang menggambarkan topografi Kota Semarang hasil pengukuran tahun 2008 ditampilkan dalam Gambar 5. 
Dari Gambar 4, dapat dilihat bahwa Kota Semarang pada bagian atas antara lain Kecamatan Mijen, Kecamatan Gunungpati dan Kecamatan Banyumanik merupakan wilayah perbukitan dengan elevasi sekitar $375 \mathrm{~m}$, sedangkan pada bagian bawah merupakan wilayah pesisir dengan topografi datar. Hal inilah yang menyebabkan permasalahan banjir dan rob yang sering terjadi pada wilayah ini. Dengan menggunakan peta penurunan muka tanah pada Gambar 4, dapat dilakukan proyeksi untuk mengetahui DEM kondisi existing dan mendatang. DEM pada konsisi mendatang diproyeksi untuk tahun 2031. Pemilihan tahun ini sesuai dengan RTRW Kota Semarang yang periode berlakunya mulai dari tahun 2011 sampai dengan tahun 2031. Adapun hasil proyeksi DEM tersebut dapat dilihat pada Gambar 6.

Analisis hidrologi diperlukan untuk menentukan besarnya debit banjir rencana. Hal yang terlebih dahulu dilakukan adalah menentukan DAS dan sub sistem drainase dari Sungai Tenggang dan Sringin.
Pembagian DAS dan sub sistem drainase pada penelitian ini mengacu pada Dokumen Masterplan Drainase Kota Semarang tahun 2007. Gambar pembagian DAS dan sub sistem drainase Tenggang dan Sringin ditunjukkan pada Gambar 7. Berdasarkan Dokumen Masterplan Drainase Kota Semarang (PT. Tera Buana, 2007), DAS Tenggang terbagi menjadi 81 sub sistem drainase, sedangkan DAS Sringin terbagi menjadi 26 sub sistem drainase. Pembagian sub sistem drainase ini berdasarkan daerah layanan drainase pada masingmasing saluran drainase pada wilayah tersebut.

Analisis curah hujan daerah maksimum tahunan dilakukan dengan menggunakan metode Thiessen. Cara ini memperhitungkan luas daerah yang diwakili oleh stasiun yang bersangkutan untuk digunakan sebagai koefisien dalam menghitung hujan maksimum harian rata-rata daerah, atau biasa disebut koefisien Thiessen (C). Gambar polygon Thiessen yang menggambarkan pengaruh masing-masing stasiun terhadap DAS Tenggang dan DAS Sringin ditampilkan dalam Gambar 8

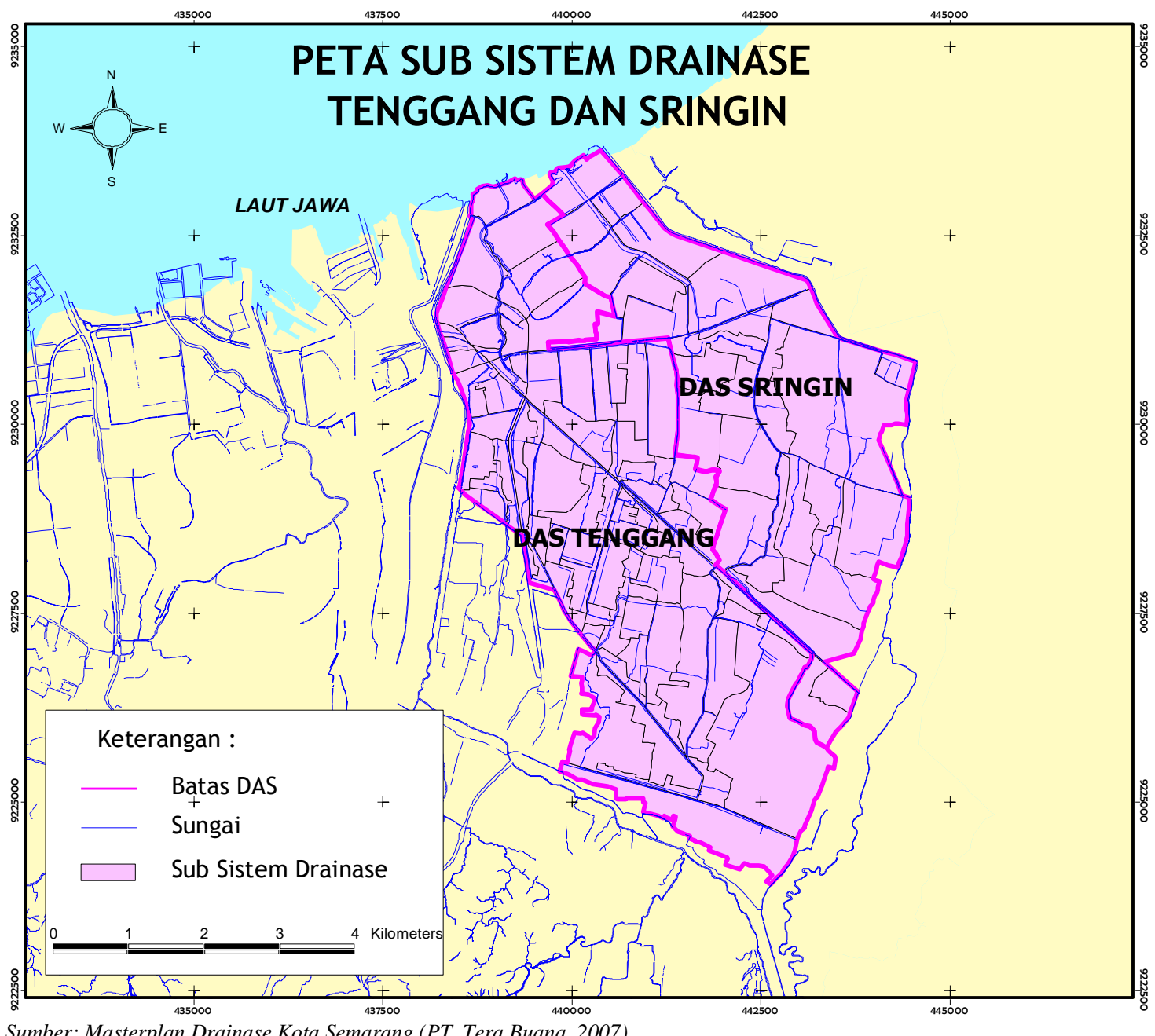

Sumber: Masterplan Drainase Kota Semarang (PT. Tera Buana, 2007)

Gambar 7. Peta DAS dan sub sistem drainase Tenggang-Sringin 


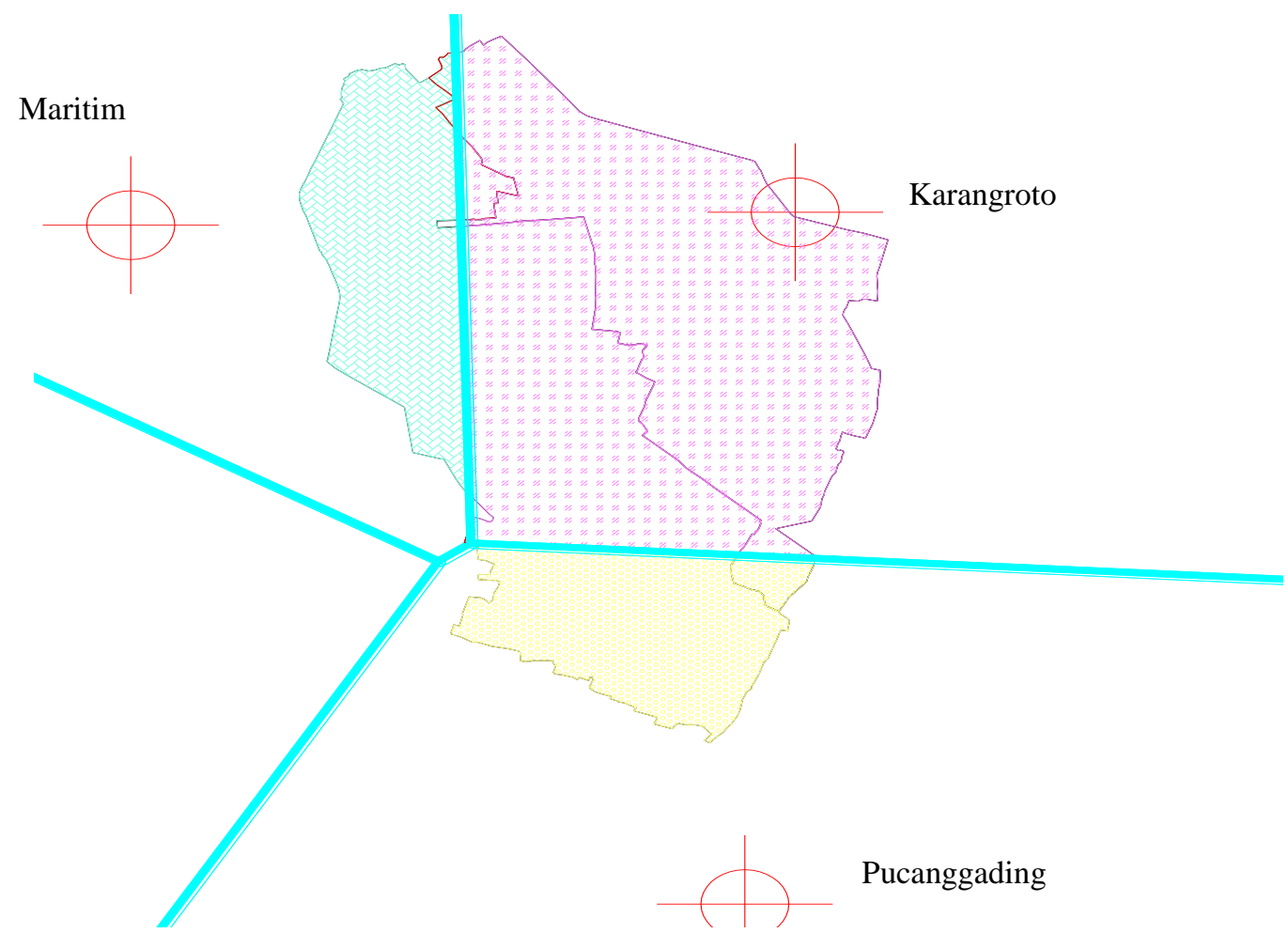

Gambar 8. Poligon Thiessen DAS Tenggang dan DAS Sringin

Tabel 1. Nilai koefisien Thiessen $\left(C_{i}\right)$

\begin{tabular}{rlrrrr}
\hline \multirow{2}{*}{ No } & \multirow{2}{*}{ Stasiun } & \multicolumn{2}{c}{ Luas $\left(\mathbf{m}^{\mathbf{2}}\right)$} & $\begin{array}{c}\text { Koef. Thiessen } \\
\text { DAS Tenggang }\end{array}$ & $\begin{array}{c}\text { Koef. Thiessen } \\
\text { DAS Sringin }\end{array}$ \\
\cline { 3 - 4 } & DAS Tenggang & DAS Sringin & & 0,31 & 0,01 \\
1 & Maritim & $6,970,318.34$ & $183,258.90$ & 0,42 & 0,96 \\
2 & Karangroto & $9,225,352.36$ & $14,608,781.14$ & 0,27 & 0,03 \\
3 & Pucanggading & $5,944,266.84$ & $413,155.25$ & 1,00 & 1,00 \\
\hline
\end{tabular}

Hasil analisis curah hujan rencana dalam beberapa periode ulang untuk masing-masing DAS ditampilkan pada Tabel 2. Perhitungan curah hujan rencana tersebut akan digunakan sebagai input didalam analisis debit banjir. Kala ulang yang digunakan dalam studi ini adalah 25 tahun. Pemilihan kala ulang ini berdasarkan pada Dokumen Masterplan Drainase Kota Semarang, 2007.

Hasil analisis curah hujan rencana digunakan untuk analisis debit banjir. Analisis debit banjir dalam penelitian ini menggunakan software HECHMS. Curah hujan rencana yang digunakan sebagai input direncanakan menggunakan periode ulang 25 tahun. Basin model pada HEC-HMS dan hydrograph debit banjir output model HEC-HMS ditampilkan pada Gambar 10.

Tabel 2. Hujan rencana

\begin{tabular}{cccc}
\hline No & $\begin{array}{c}\text { T } \\
\text { (tahun) }\end{array}$ & $\begin{array}{c}\text { DAS Tenggang } \\
\text { Xt (mm) }\end{array}$ & $\begin{array}{c}\text { DAS Sringin } \\
\text { Xt (mm) }\end{array}$ \\
\hline 1 & 2 & 84,5 & 108,7 \\
2 & 5 & 106,8 & 140,8 \\
3 & 10 & 118,4 & 162,3 \\
4 & 20 & 128,0 & 183,2 \\
5 & 25 & 130,8 & 189,9 \\
6 & 50 & 138,8 & 210,8 \\
7 & 100 & 146,0 & 232,0 \\
\hline
\end{tabular}




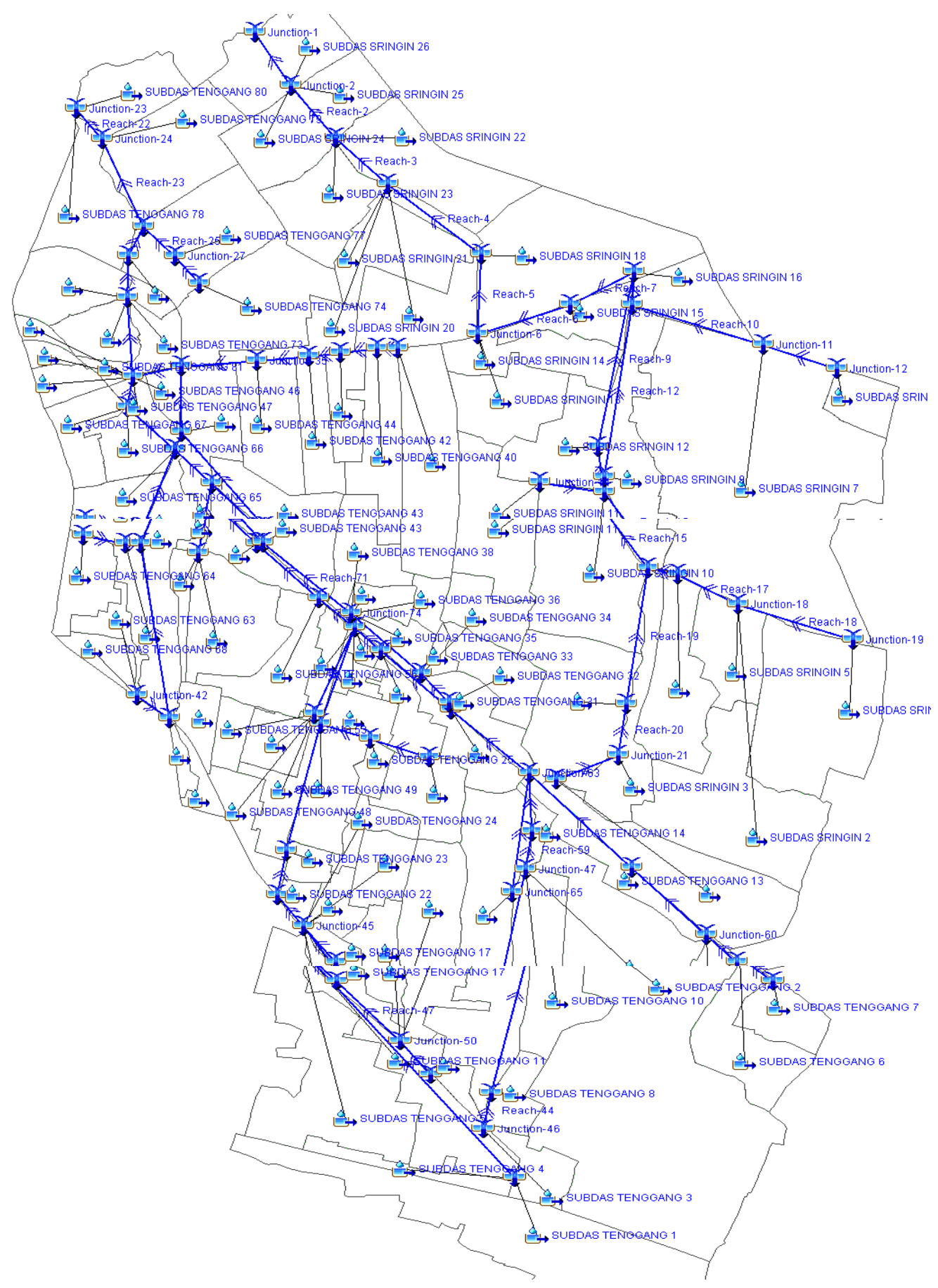

Gambar 9. Basin model HEC-HMS DAS Tenggang dan DAS Sringin 


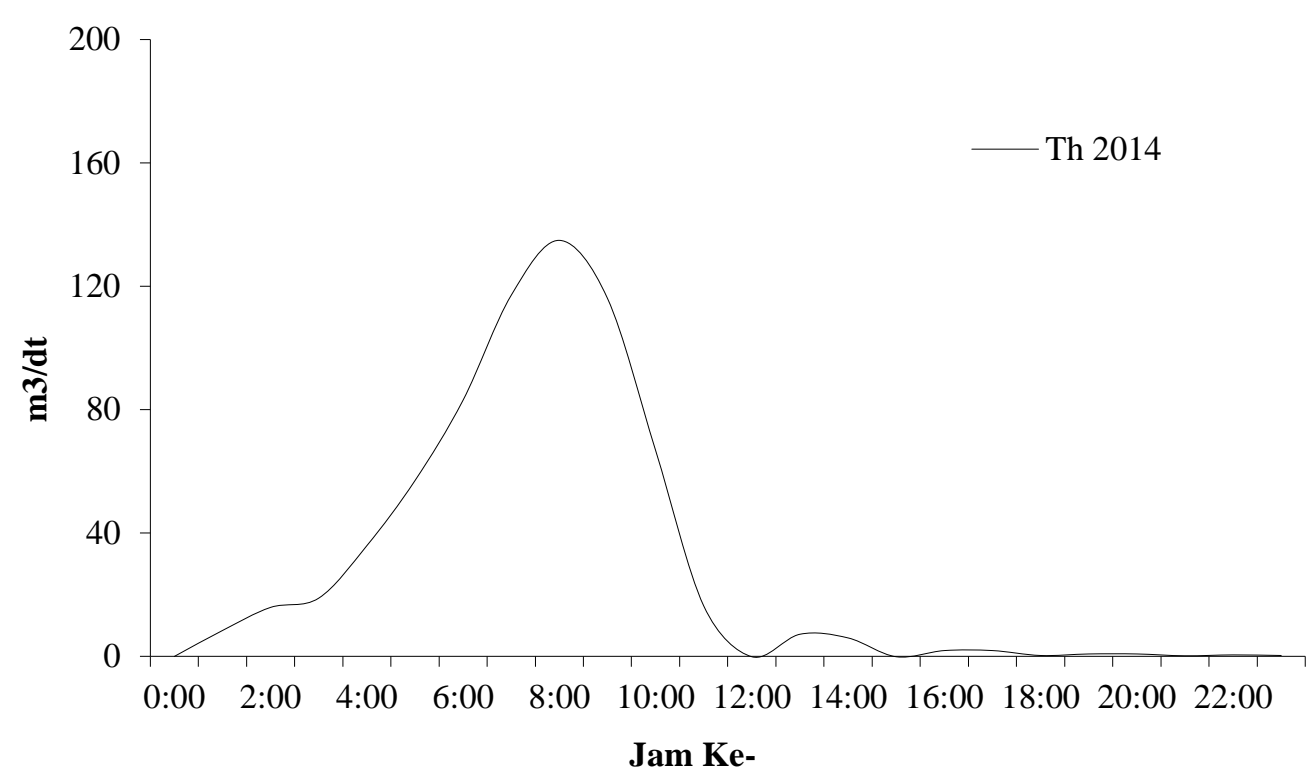

a)

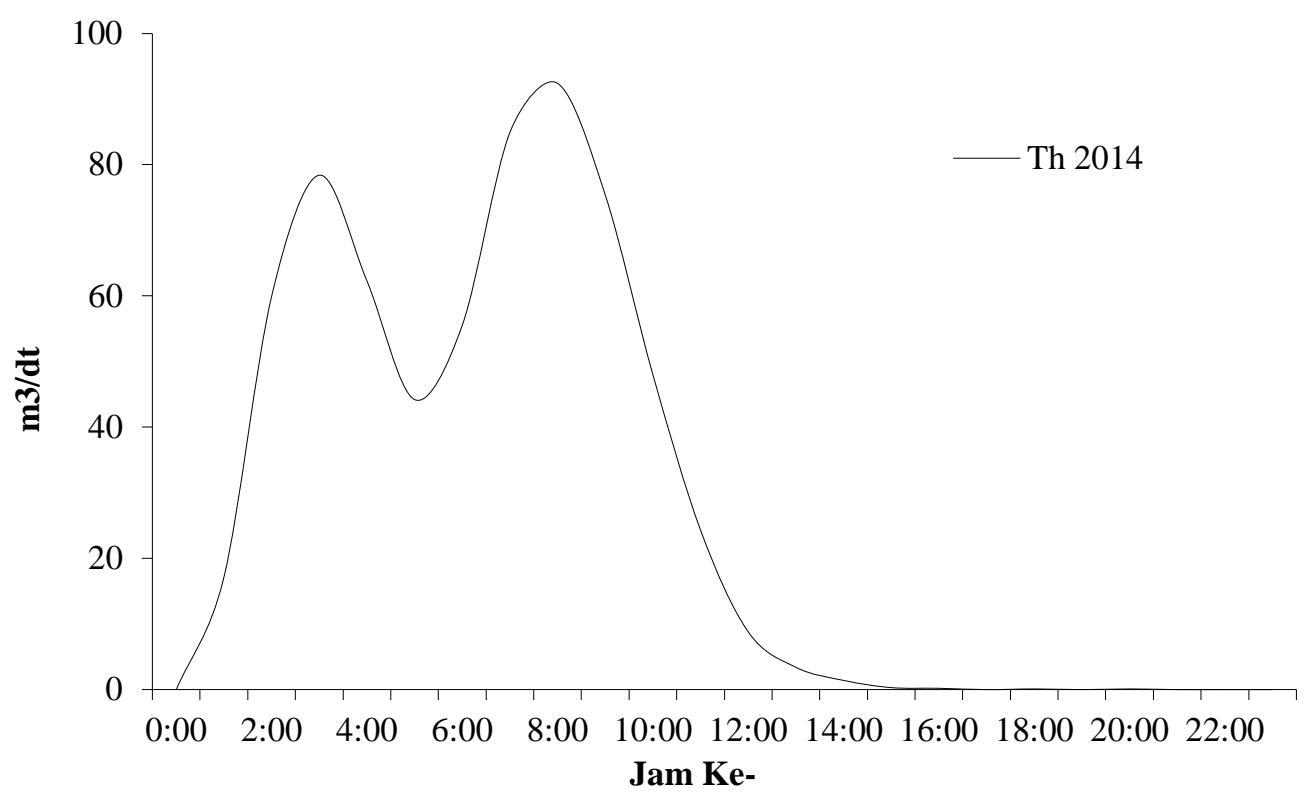

b)

Gambar 10. a). Hydrograph Banjir DAS Tenggang $\mathbf{Q}_{25}$, b). Hydrograph Banjir DAS Sringin $\mathbf{Q}_{25}$

Dari Gambar 10, diketahui bahwa debit banjir puncak DAS Tenggang untuk kala ulang 25 tahun adalah 134,9 m3/dt, sedangkan DAS Sringin sebesar $92,4 \mathrm{~m}^{3} / \mathrm{dt}$. Data debit banjir puncak ini nantinya akan digunakan dalam analisis hidrolika untuk mengetahui profil tinggi muka air pada masing-masing saluran.

Analisis profil muka air sungai (hidrolika) dalam penelitian ini menggunakan software HEC-RAS. Data yang digunakan antara lain:

a. Potongan melintang Sungai Tenggang dan Sungai Sringin b. Debit banjir hasil analisis HEC-HMS.

c. Data pasang surut tiap-tiap jam dari BMKG Maritim Semarang.

Setelah dilakukan input data, model kemudian di running untuk mendapatkan hasil berupa profil mukaair. Hasil running model HEC-RAS dicontohkan pada Gambar 9.

Gambar 9 merupakan hasil running model HECRAS. Dari model ini, diperoleh profil muka air pada masing-masing cross section. Selain itu, diperoleh pula profil muka air memanjang sungai 
pada masing-masing reach yang mewakili sungai. Output model HEC-RAS berupa muka air digunakan untuk membuat DEM muka air banjir. Setelah diperoleh DEM tinggi muka air banjir, dilakukan penggambaran genangan banjir dan rob dilakukan dengan bantuan program Arc GIS dengan menggunakan data tinggi muka air tersebut. Metode yang digunakan antara lain dengan menumpangsusunkan peta DEM tinggi muka air banjir yang diperoleh dari hasil analisis HEC-RAS dengan DEM muka tanah asli untuk kondisi existing. Untuk mendapatkan genangan kondisi mendatang, dilakukan tumpang susun DEM tinggi muka air banjir DEM mendatang yang telah dianalisis dengan faktor land subsidence. Hasil penggambaran genangan banjir dan rob di DAS Tenggang dan DAS Sringin ditampilkan pada Gambar 12.

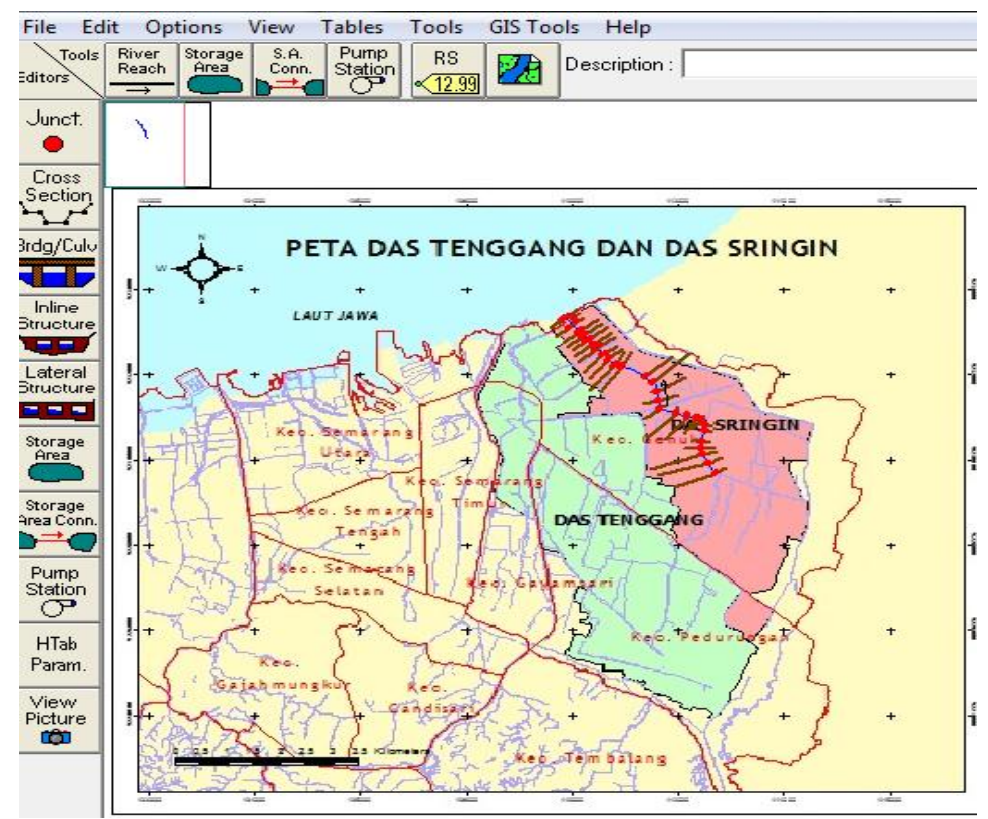

a)

skenario Plan: Plan 20 2/9/2015

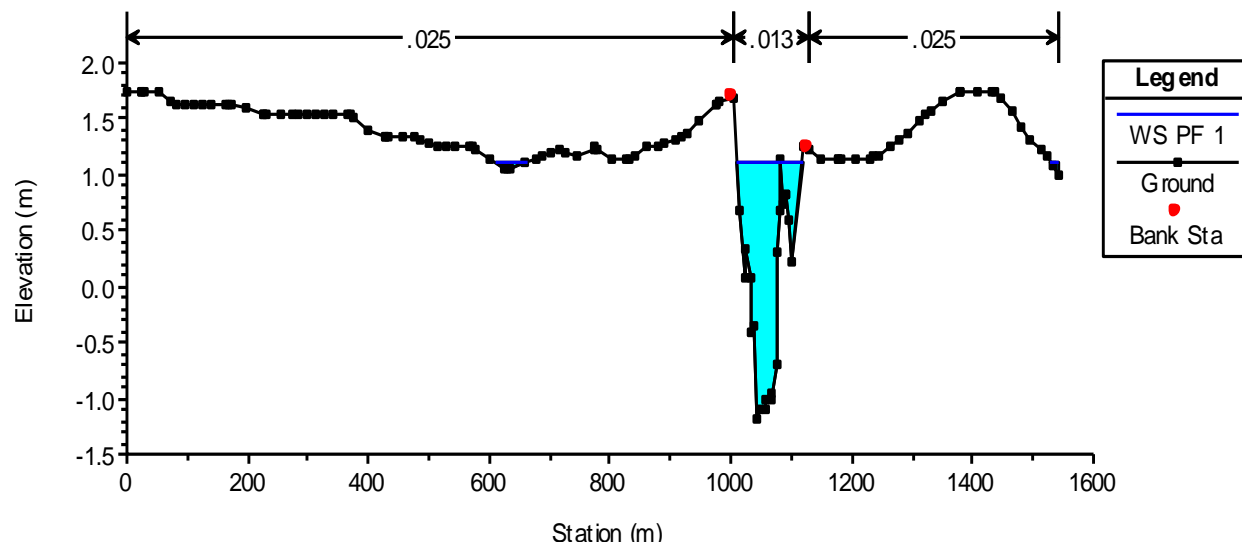

b)

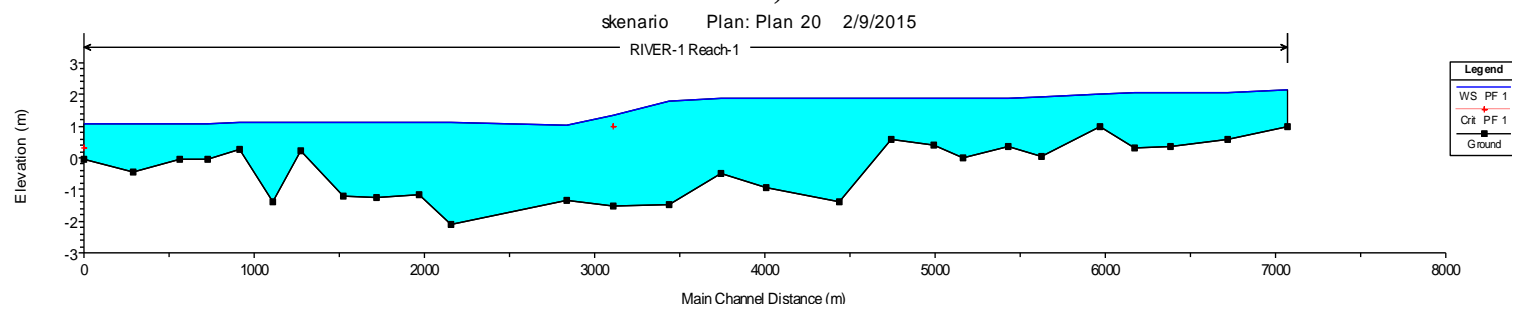

c)

Gambar 11. a). Geometri model HEC-RAS, b). Output model berupa muka air pada cross section sungai, c). Output model muka air pada potongan memanjang sungai 


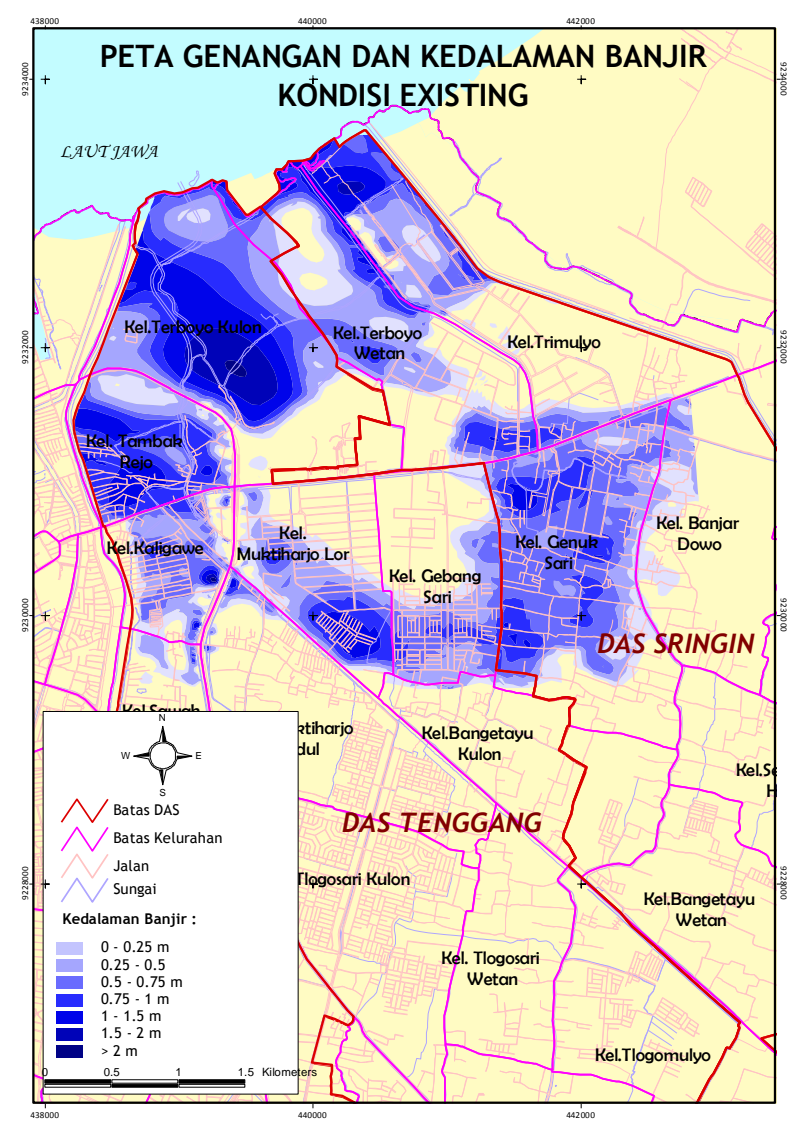

a)

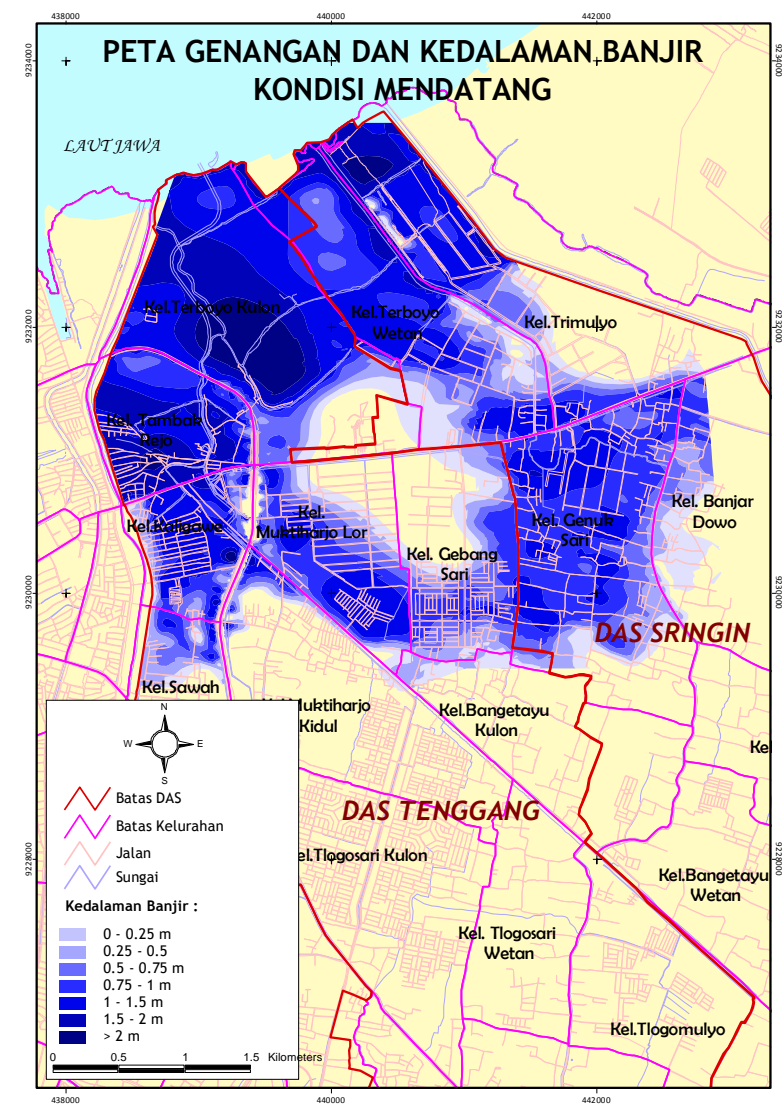

b)

Gambar 12. a). Genangan banjir dan rob existing, b). Genangan banjir dan rob tahun 2031 
Tabel 3. Luas dan kedalaman genangan banjir dan rob

\begin{tabular}{crr}
\hline Kedalaman $(\mathbf{m})$ & \multicolumn{2}{c}{ Luas (Ha) } \\
\cline { 2 - 3 } & Eksisting tahun 2014 & Tahun 2031 \\
\hline 2 & 1,34 & 46,58 \\
$1.5-2$ & 25,93 & 153,87 \\
$1-1.5$ & 102,54 & 349,30 \\
$0.75-1$ & 175,80 & 280,78 \\
$0.5-0.75$ & 275,43 & 170,16 \\
$0.25-0.5$ & 270,99 & 133,53 \\
$0-0.25$ & 168,19 & 126,69 \\
\hline Total & 1020,23 & 1260,91 \\
\hline kontribusi terhadap genangan & & $1,39 \%$ \\
banjir dan rob per th $(\%)$ & & \\
\hline
\end{tabular}

Dari hasil analisis diperoleh bahwa pada kondisi existing, luas genangan banjir dan rob adalah $1.020,23$ ha. Pada masa mendatang dengan kurun waktu 2014-2031, dengan adanya faktor land subsidence genangan banjir dan rob meningkat menjadi 1.260,91 ha atau meningkat sebesar 240,68 ha bila dibandingkan dengan tahun 2014. Dari kenaikan luasan genangan, dapat disimpulkan kontribusi faktor land subsidence terhadap kenaikan genangan banjir dan rob di DAS Tenggang dan Sringin sebesar 1,39\% per tahun.

\section{Kesimpulan}

Dari hasil dan pembahasan di atas, dapat disimpulkan beberapa hal sebagai berikut:

1. Penurunan muka tanah maksimum di Kota Semarang sebesar $5,58 \mathrm{~cm}$ per tahun. Wilayah dengan nilai penurunan muka tanah yang cukup tinggi berada pada wilayah pesisir Kota Semarang bagian Timur khususnya Kecamatan Genuk, Kecamatan Gayamsari dan Kecamatan Semarang Timur.

2. Pengaruh land subsidence terhadap peningkatan luas genangan banjir dan rob di DAS Tenggang dan Sringin selama kurun waktu tahun 2014-2031 sebesar 23,6\% atau $1,39 \%$ per tahun.

\section{Saran}

Penelitian ini menggunakan data pengukuran land subsidence dengan rentang waktu yang pendek yaitu tahun 2008 dan 2011. Untuk mendapatkan hasil yang lebih akurat, diperlukan data pengamatan land subsidence dengan jangka waktu yang lebih panjang.

\section{Daftar Pustaka}

Abidin, H.Z., Andreas, H., Gumilar, I., Sidiq, T.P., Gamal, M., Murdohardono, D., Supriyadi, Fukuda,
Y., 2010. Studying Land Subsidence in Semarang (Indonesia) Using Geodetic Methods, FIG Congress.

Asdak, C., 1995. Hidrologi dan Pengelolaan Daerah Aliran Sungai, Gadjah Mada University Press, Yogyakarta.

Corps of Engineers, 2010. Hydrologic Engineering Center's River Analys System User's Manual, U.S. Army, Washington DC.

PT. Tera Buana Manggala Jaya, 2007. Penyusunan Dokumen Masterplan Drainase Semarang, Bappeda Kota Semarang, Semarang.

Suripin, Wirasatriya, A., \& Hartoko, A., 2006. Kajian Kenaikan Muka Laut sebagai Landasan Penanggulangan Rob di Pesisir Kota Semarang, Jurnal Pasir Laut, Vol. 1, No.2, 31-42.

Wahyudi, I., 2001. Uji Hipotesis terhadap Faktor Penyebab Banjir Rob Kota Semarang, Prosiding Seminar Nasional ITS. ISBN.

Wahyudi, S. I., 2010. Perbandingan Penanganan Banjir Rob di La Briere (Prancis), Rotterdam (Belanda) dan Perspektif di Semarang (Indonesia), Riptek, Vol.4, No.II, 29 - 35.

Water Supply and Water Resources Division National Risk Management Research Laboratory, 2009. Storm Water Management Model User'S Manual, United States Environmental Agency, Cincinnati.

Yuwono et al., B. D., 2013. Analisa Geospasial Penyebab Penurunan Muka Tanah di Kota Semarang, Prosiding SNST ke-4 ISBN 978-60299334-2-0, 1-8. 